DOI https://doi.org/10.36059/978-966-397-158-2/191-208

\title{
TRANSFORMATION OF POLITICAL CULTURE IN THE SOCIO-CULTURAL CONTEXT OF UKRAINE
}

\section{Sushko A. I.}

\section{INTRODUCTION}

Transformational changes occurring in Ukraine at the turn of the XXXXI centuries significantly affect political and socio-cultural processes. Democratization of society, formation and realization of new cultural and spiritual values testify to the establishment of Ukraine as a unique local civilization. It is in this context that the place of our country in the European and global world space should be determined. The study of political culture becomes more relevant from the standpoint of combining the best examples of the European Union's cultural standards on the one hand, and the preserved and enhanced spiritual values and national traditions on the other.

In order to analyze the processes of functioning of the political culture of our society in the historical understanding of the specifics of its formation, the author considers that special attention should be paid to the possibilities of socio-cultural approach. Carrying out such an analysis of various phenomena of manifestation of political culture allows to expand considerably the subject field of its research and on this basis to comprehend the most effective models of political culture, which have historically been formed, which correspond to modern needs of both citizens and society as a whole.

Foreign and national science in recent decades has been enriched by a large number of works that take into account various aspects of the development of political culture in the modern civilization. At the time, a number of issues need further attention. Thus, the features of the formation of political culture of the Ukrainian people under the influence of internal and external factors are underdeveloped, which led to a change in the forms of manifestation of political culture, the peculiarity of its evolution in the context of the civilizational choice of Ukraine.

The study of this problem is based on the use of classic methodological tools - systematicity, historicism and objectivity. This allows us to investigate thoroughly the dialectic of socio-cultural processes within which the formation of political culture of our people was. The author prefers a 
civilizational approach in the analysis of the peculiarities of the historical process, which allows, first, to more fully reveal the interaction of political culture with the mentality, spirituality, and secondly, to embed organically this complex process as an integral part of the European civilization paradigm. In this way the pattern and tendency of the development of the identity of the political culture of the nation are revealed, which allows to overcome the crisis phenomena in the socio-cultural processes of modern Ukraine more effectively.

\section{Understanding the historical processes of transformation of political culture}

A positive factor in the development of theoretical construction is the understanding of the concept of «political culture» in the broad sense. The authors of this approach include in its composition both the basic elements and the formed political traditions, norms of socio-political activity, ideas, concepts and beliefs concerning the interaction of political institutions of the state and society. Within this framework, political culture is defined from the standpoint of the characteristics of qualitative traits of different social actors in the sphere of political relations. In essence, all supporters of this approach emphasize the long absence in the political field of Ukraine the activities of democratic institutions and, consequently, the inability to shape fully the modern political culture.

In developed democracies, civil society has a role in transforming political culture. It significantly influences the activity of the authorities and the state administration and through the existing political and legal model of interaction the process of becoming a democratic type of political consciousness is underway; the political behavior of an active citizen is formed. Such a variant receives the necessary stability only in stages and with the condition of entering into real political activity of the majority of citizens, representing all social groups of a given society. It is being implemented more effectively, and, most importantly, new institutions are operating, the search terms for finding a way out of the crisis are shortening, civilizational landmarks are coming into force more quickly.

It is important that the socio-cultural approach allows us to comprehend more adequately contemporary socio-political realities, in particular, to disassociate from the one-sided vision of the political system and its institutions - firstly, and secondly - the political culture itself is seen as a characteristic of the full realization of all the essential possibilities of the sub political relations. Therefore, more and more attention is being paid to the analysis of the interpretation of the concept of «sociocultural» within the 
dominant tendency of modern humanities to consider human activity in the cultural dimension. Various problems of socio-cultural identity, sociocultural world of Ukraine are revealed in the works of L. Males, A. Sokuryansky, M. Yurii ${ }^{1}$. It is also worth noting the works directly devoted to the civilization understanding of the culture of Ukraine. First of all, it is the groundwork of L. Hubernsky, V. Andrushchenko, Y. Kalakura, M. Mikhalchenko, O. Rafalsky and V. Sheiko².

The authors of these and other works view the theory of civilizations as a more universal paradigm, which qualitatively blends with the sociocultural view of history, compared to the formative approach that dominated sociopolitical analysis by the end of the twentieth century. A new look at the factor of culture in collective self-identification is gradually changing the priority of the economic basis, which, in the opinion of the proponents of the traditional approach, was decisive in characterizing the functioning of any society at all stages of its development. Of course, the problem of cultural resources, the ability to dispose adequately of them is quite a multifaceted and ambiguous problem. Her new understanding is seen as a field of multiplicity, differences, gaps in historical development. «Culture is a manifestation of a person's interpretive subjectivity in relation to himself and his world. It is simply identical to the mental process of delivering or creating content without which human life would be impossible». ${ }^{3}$ Thus, according to the opinion of L. Nagorna, «the focus of the analysis is there, and this is where the ethos is - the space of values, the ideal objects that outline the circle of priority representations of man. It is the values that lay the spiritual-orientation foundation of social life, which is equally interesting to historians and political scientists».. ${ }^{3}$ The author emphasizes that the reflexive potential of historical culture evaluates, first and foremost, its socio-cultural space - with a set of values and meanings circulating in it, and political forces, as a rule, adversely affect the state of socio-cultural reflection, creating a delineation of levels of strategy and tactic. It is permissible to say, the author thinks, even about the existence of different

\footnotetext{
${ }^{1}$ Малес Л. Розуміючий потенціал соціокультурного аналізу //Якісні дослідження в соціологічних практиках. Навч. посібник. К, 2009. С. 77-95.

Юрій М. Ф. Соціокультурний світ України: Моногр. 2-е вид. К.: Кондор, 2004 С. 736.

2 Губернський Л., Андрущенко В., Калакура Я., Михальченко М. Ідеологія, особистість, методолого-світоглядний аналіз. К.: Знання України, 2002. 580 с..; Калакура Я., Рафальський О., Юрій М. Українська культура: цивілізаційний вимір. К.: ІПіЕНД ім. І. Ф. Кураса НАН України, 2015. 496 с.; Шейко В. Культура України в глобально-цивілізаційному вимірі (історико-методологічні аспекти). К.: Інститут культурології НАМ України, 2011. 624 с.
} 
historical subcultures in Ukraine, subordinated to different political goals and oriented towards opposite cultural patterns. ${ }^{3}$

In the post-socialist space, Ukraine is one of the countries with the longest transit, in addition, with deviations in movement. In fact, our country is in the midst of a consolidated democracy and a semi-authoritarian regime. According to the opinion of the most researchers, transit is a concept that refers to changes in the political regime and has a beginning and an end. Sometimes it is interpreted as a synonym for transformation, or transition, that is, it depends on the meaning put into these concepts by various authors.

Transformation, as a concept, is used in relation to objects with complex structures that have changed significantly, and as a rule, for the better. The trajectory of socio-political transformations in Ukraine has a long period and, at certain intervals, is less definite in comparison with the countries in which transit has ended with the consolidation of democracy.

Within the framework of socio-humanitarian knowledge, the process of historical discourse is increasingly viewed in a cultural context. The imperative of time is contextuality - the need to study any historical phenomenon in the context of the sociocultural environment that gave birth to it. Modern epistemology strongly rejects the search for universal theoretical constructs that are suitable for analyzing the history of different times and peoples, says A. Nagorna. It is only through the cultural context in which it is destined to exist that one can understand the way of thinking of the person of the past and the framework of his «life world». ${ }^{4}$ Therefore, it is natural for skeptics to be able to create a common theory of socio-cultural evolution and optimistic about the prospect of a comparative analysis of cultural traditions, separated from each other by millennia ${ }^{5}$.

In general, historical memory is quite functional and has its own cycles in different socio-historical conditions. Thus, the transformation processes of the late and XVII and XX centuries increased the interest in our own historical past, as a result, the consciousness of society increased.

It is not the formational but the civilizational approach that is most successfully combined with socio-cultural history. Although its methodology requires further development, the achievements of this approach allow revealing more fully the originality of national cultures, including the Ukrainian one. A political approach that will reveal the influence of the

${ }^{3}$ Нагорна А. Історична культура: концепт, інформаційний ресурс, рефлексивний потенціал. К.: ІПіЕНД ім.І.Ф.Кураса НАН України, 2014. С. 53-56.

${ }^{4}$ Нагорна А. Історична культура: концепт, інформаційний ресурс, рефлексивний потенціал. К.: ІПіЕНД ім.І.Ф.Кураса НАН України, 2014. С. 116

${ }^{5}$ ibid C. 117. 
political systems of Kyiv Rus, Galicia-Volhynia principality and the Cossack-Hetman state, as well as the cultural process and profound changes in the mentality of Ukrainians, their way of life and worldview, should also be considered promising.

The interaction of political and cultural processes is especially relevant during periods of instability at bifurcation points. For Ukraine, these are structural displacements and their disintegration, changes «centerperiphery». In the context of the synergistic approach, transitions become the field of study of the problem of historical alternatives, the possibilities of changing the vector of development, the combination of traditions and modernizations.

In today's context, the scientific discourse of marked research is becoming the focus of humanitarian thought in Ukraine. The phenomenon of borderlands, which O. Kryvitska points out, is that in the space of its interaction new forms of solidarity of social communities are emerging, socalled, transformational social networks are being formed. In the border areas there are processes of layers of different socio-cultural markers, which affects their «privileged» status, provides the opportunity for various communications. The boundary of an element of spatial organization is transformed into factors of influence, providing a new quality of development of the border socio-cultural and mental space ${ }^{6}$. It is here as in the most intense areas of the cultural space that the choice of a further life strategy of a person is made. Overall, the intense functioning of the crossborder region generates a kind of culture.

Research into the historical competition of different strategies - settled agriculture and nomadic in forest-steppe zones - has started quite intensively. Dominance has shifted from one side to the other within a certain field of ethnic unity. Controversial in this context is L. Gumilev's statement about the combination of Desh-i-Kipchak and Kyiv Rus in one multi-ethnic state (XII-XIII centuries) ${ }^{7}$. Even more controversial is the position of another author (M. Aji) on the Turkish character of Kyiv and Ukraine $^{8}$. More justified is the picture of showing the victory of agricultural culture from the standpoint of civilization approach. Of course, a significant segment of the nomadic world has entered a new whole. This process

\footnotetext{
${ }^{6}$ Кривицька. О. Дискурс пограниччя в соціокультурних дослідженнях: теоретичнометодологічні аспекти. Наукові записки: ІПЕНДім. І. Ф. Кураса НАН Украӥни. - 2015 Вип. 4(78). С. 173-174.

${ }^{7}$ Гумилев Л. Н. Древняя Русь и Великая Степь. М.: Товарищество «Клышников Комаров и К», 1992. С. 327.

8 Аджи М. Европа, Тюрки, Великая Степь. М.: ООО «Издательство АСТ», 2004. C. 67-80.
} 
stretched across time and space, and the Cossack community was born in the buffer strip. As each transition form, it disappears over time.

As a segment of socio-cultural history we can also consider the mentality of certain social groups, which most fully reflects the picture of the world of different stages of development of our society. In this context, mentality is seen as a historical phenomenon, that is, it embodies a certain level of social and individual consciousness, the associated spectrum of culture and behaviors as the inheritance of certain ethnogenetic memory. The historical problems of mentality, in particular the sources and archetypes of the Ukrainian mentality, considered in the collective monograph by M. Popovych are quite thorough ${ }^{9}$. He and other well-known scientists (S. Krymsky, M. Mikhalchenko, Y. Pavlenko) hold the opinion that Ukrainian society has always belonged to a larger system than the country and has its history and structure of many elements.

The problems of assimilation and acculturation, intercultural interaction and synthesis are becoming more relevant and debatable. And if for a long time they have been paying attention to the processes of assimilation, which leads to the loss of their own cultural specificity of certain social groups (princes, Ukrainian nobility), then the modern researchers shift the emphasis to the study of permanent acculturation, which forms a border culture. They are defined by multiculturalism, the appearance of a marginal person - a kind of «cultural hybrid». Being a process of mutual influence of cultures, the perception by one ethnos of the culture of another, acculturation also promotes marginal forms, often condemning people to exist in several cultural worlds at the same time. Such individuals are celebrated or, by bilingualism, have more independent views and a broader choice, or a negative process of subordination to a dominant group of society, which in most cases marginalizes a person, causes a sense of social dichotomy, bifurcation. The third variant has also been actively studied, when the sociocultural environment of the cross-border region is a realm where two cultures intertwine and where a space-absorbing culture combines and integrates the features of two cultures. And at the center of this encounter is a marginal man struggling to be a key figure between the two lights ${ }^{10}$.

${ }^{9}$ Проблеми теорії ментальності / Ред. М.В. Попович . К., Науккова думка, 2006. 404 с.

${ }^{10}$ Калакура Я., Рафальський О., Юрій М. Українська культура: цивілізаційний вимір. К.: ІПіЕНД ім. І. Ф. Кураса НАН України, 2015. 496 с.; Шейко В. Культура України в глобально-цивілізаційному вимірі (історико-методологічні аспекти). К.: Інститут культурології НАМ України, 2011. С. 280. 
Worldview is a broad concept, but less related to adaptive elements, so it is better to use the term «world picture». Different social groups within the domestic culture in the same period had different pictures of the world.

Being a fundamental pillar of human existence, the picture of the world reflects the connections of man with the world, which objectively exist in practice, and it fixes those transformations that are productive in nature. The core of the picture of the world is formed by socio-cultural constants, which essentially make up the system of rules of perception, thinking, action. At the same time, the external environment significantly influences them and thus creates the conditions for new manifestations of human behavior. In the history of different socio-cultural communities, previous orientations have been displaced to the periphery of the world picture and exist in a latent form.

The process of becoming a Ukrainian nation took place in different socio-cultural coordinates, and the states that owned Ukrainian lands in the XIII - XVII centuries were politically and even civilly quite different. Some were based on the principles of despotism, while others had representative government bodies. Due to the heterogeneity, different ethnic groups developed in cultural settings, which differed significantly from each other, and this affected political culture.

Not having state support, the Ukrainian ethnic group in the process of acculturation got into a situation of crisis of its own identity, which is especially characteristic for the elitist part of society. After coming under the rule of the Grand Duchy of Lithuania, there was no own center of concentration of the elite. The process of study in European cities made it possible to get acquainted with the social achievements and legal institutions of the West, which contrasted sharply with the samples of their own ethnicity. The inferiority complex was also facilitated by the name «Mala Rus», which appeared in the XIV century and spread again in the XVII century on church and political spheres. In the XVIII century the name «Malorosia», made of the name «Mala Rosia», only concerned the Hetmanate, where the Malorosia identity was formed. At the end of the century, this process was suppressed by the efforts of the imperial center.

The idea of free people who have chosen a military destiny and serve nationals is based on the cultural model of Zaporozhian Cossacks. Formed in the fronts of the agricultural and nomadic worlds, the Cossacks were able to create a unified system with other lands, and their culture was perceived as part of the Ukrainian tradition. This made it possible to take a leading role in establishing their own statehood, to form an administrative and political system throughout Ukraine, which has long operated on the Left Bank. Thus, 
being the creator of new values and ideals, the Cossacks spread them to all regions of Ukraine. The authors of political treatises of the Hetman era were aware of the continuity with previous eras of the statehood of their people. It did not matter in the future for the development of the social-state idea of Ukrainians ${ }^{11}$.

It can be stated that significant socio-cultural changes of the XVIXVII centuries. In general, they were in line with pan-European processes, including state-building, moreover, Ukrainian society was directly involved in them. Social and religious conflicts at the turn of the Middle Ages and Modern times were quite long and bloody all over Europe and Ukraine is no exception here. Therefore, fundamental trends in Ukrainian society, represented by Orthodox fraternities, militant anti-Catholic polemicists, and grassroots social movements, whose political leader was often Zaporozhian Sich, became uncompromising ${ }^{12}$. But, in these extremely difficult conditions, it is Cossacks who, to a great extent, owe it to the selfpreservation of the identity of the Ukrainian nation.

Ideas of humanism and the Renaissance, the myth of the Great Sarmatia, which became the epitome of the Polish-Lithuanian Commonwealth as an outpost of Christianity, were popular among the Ukrainian elite. The nobility's liberties found support in Russia-Ukraine and in some way contributed to the creation of their own historical and political identity. In the writings of humanists of Ukrainian origin, the awareness of equal partners with the Poles is clearly expressed. There are various projects of restoring the statehood of Rus within the framework of the Commonwealth (S. Orikovsky, I. Dombrovsky, K. Sakovych). In particular, such ideas became relevant in the search for a common identity of Galicia, Podillya, Volyn and Kyiv region, when these lands were in the same state after the Union of Lublin (1569). The complexity was, first, in the spiritual-religious conflict of the turn of the XVI - XVII centuries, and secondly, in the absence of real experience of political management in the Ukrainian nobility, which did not allow it to become a dominant political force in Ukrainian society. Its place was taken by the new Cossack-born elite, who embarked on a path to electing political rights by armed means ${ }^{13}$.

National liberation movements of the XVII century clearly demonstrated the process of formation of an early-modern national community, the

${ }^{11}$ Іванченко Р. П. Історія без міфів: бесіди з історії української державності : навч. посіб. 2-ге вид., переробл. і допов. К.: МАУП, 2006. С. 211.

12 Юрій М. Ф. Соціокультурний світ України: Моногр. 2-е вид. К.: Кондор, 2004. C. 296 .

${ }^{13}$ Шевченко Н.В. «Ягелонська спадщина» у світлі сучасних українських історичних студій. Історичний архів. Миколаїв, 2008. Т. 1. С. 34-35. 
concept of Ukraine as a mother country, the beginning of their own statehood.

Ethnic and then national consciousness is a central component of the mentality of all sociocultural entities and individuals.

The Enlightenment period in Ukraine contributed to the creation of a more open-ended culture, in which several independent zones coexisted, with each other being primarily sacred and secular. They had different languages of use, but there was no rigid demarcation and legal boundaries. Often, authors move freely from one language to another, depending on the purpose of the work. Being in different socio-cultural situations formed by the interaction of the Catholic and Orthodox worlds, which supported respectively the Commonwealth and the Russian Empire, Ukrainian culture was able to use this situation to form many mixed forms. This did not preclude discussions and the emergence of new forms of national liberation movement.

The continuation of the traditions of the Middle Ages in the sacral zone was especially clearly manifested in the system of education, the arts, above all, in icon painting, chronicle, and teacher literature. The new baroque aesthetics allowed religious values to be developed on a new basis without negating traditions. Thus, in baroque forms of religious poetry, the secular was combined with the sacred, which had not been the case before. In this way, the synthesis of styles gave rise to new phenomena becoming a sign of Ukrainian culture of modern times, as well as the constant fluctuations of many authors between the archaic of the Middle Ages and the new Baroque forms. Moreover, there were different levels of baroque and this allowed recreating the reality, to break the line between «high» and «low» themes, and most importantly to change the opposition of the sacred and secular to their rather peaceful coexistence.

More and more scholars are linking the time of nation birth in Europe to the first translations of the Bible into national languages. Printing in the four Gospels in ancient Ukrainian literary language helped to establish ethnic identity. According to the concept of B. Anderson in the XVII century, the emergence of national histories and printed educational literature more intensively accelerate the national consciousness, which shape the perception of each people about themselves, its mission in the world - the national idea.

Thus, according to the author, these factors began to influence the basic ethnic characteristics of Ukrainians, updating their mentality and subsequently, to determine the peculiarities of the political culture close to the values of the European world. 


\section{Sociocultural factor of the national creation process in Ukraine in the XIX - beginning of the XX centuries}

Researchers on issues of national relations emphasize the speed of emergence of national communities as the foundation of socio-cultural ties in the modern times.

Specific to this approach is Ya. Gritsak's research on the process of natiogenesis. He considers the time of the appearance of the "early-modern» Ukrainian nation of the XVI-XVII centuries, and the modern - the XIXXXI centuries. ${ }^{14}$ In the second half of the XIX century the process of politicization of the Ukrainian society based on the national idea begins. This period was a turning point for a new era - the Modern Age, when political nations and their political unions are dominant. Political becomes a national movement and peoples without a state. In this concept, the Ukrainian national movement was born on the basis of cultural and linguistic requirements, and in the XX century. It is clearly politicized, especially in the Austro-Hungarian Empire. This process contributes to the growth of political consciousness of Ukrainians.

During the XIX century the birth of a modern Ukrainian nation is taking place, which has led to the emergence of nationalism. During this period he went through a 3 phase self-development: the cultural interests of the intelligentsia; the ethnic, national identity of the intellectual elite of Ukrainian society; and at the end of the nineteenth century, it is framed into an ideology and political movement whose task was typical of nationalism in Eastern Europe - to transform the masses into a nation. Ideological and political design of Ukrainian nationalism at the turn of the 19th-20th centuries. powerful social factors also provoked ${ }^{15}$.

According to a research report prepared on the basis of a survey of 58 Ukrainian and foreign experts, the main source of significant problems of modern Ukrainian society is the lack of a national idea and common identity. «The crisis of trying to unite the quite different national conceptualizations existing in modern Ukraine leads to the lack of a clear vision of the desired end results of social transformations, the slowing of the latter and the deepening of economic decline» ${ }^{16}$.

${ }^{14}$ Грицак Я. Нариси історій України. Формування модерної української нації XIXХХ століть. К.: Генеза,1998. 279 с.

15 Касьянов Г. В. Український націоналізм: проблема наукового переосмислення. Украӥнський історичний журнал. 1998. № 2. С. 48.

${ }^{16}$ Резнік В. Теоретико-методологічні семінари в Інституті соціології НАН України. Соиіологія: теорія, методи,маркетинг. 2013. № 3. С. 182. 
The answer to the causes of such phenomena should be sought not only in social processes sufficiently enlightened by our scientists, but above all in the socio-cultural aspects of life, especially in the period of modernization. Thus, the deployment of industrialization, urbanization, general education, which constitute the essence of this phenomenon, in the territory of the Russian and Austro-Hungarian empires, despite some dynamics, were insufficient and delayed in comparison with most European countries. In essence, modernity has shaped modern Europe as a post-traditional society, dominated by individualism and the dynamism of the social system, primarily by increasing its influence on the intellectual and cultural sphere. Transformation in Ukrainian society of the XIX century under the influence of the spiritual values of modernism allows us to understand the essence of our modern life, tendencies and processes of socio-cultural development of Ukraine.

National processes are particularly controversial in traditional societies when marginalization becomes a dominant trend in crisis social systems. It proceeds in the form of a subculture of transitivity, with specific interests and values, patterns of behavior in different spheres of life ${ }^{17}$.

The abolition of the institution of the Hetmanate is a time-consuming process and finally ends in the 30's of the XIX century. This process, in fact, ended with the prospect of developing a little Russian identity, showed the impossibility of forming on this basis a self-aware political nation. «Instead of developing into a modern Malorosian national consciousness, Malorosian identity went the way of the strange Landespatriotismus, who planned the decline of the Malorosian nation.»18.

Essentially, the sociocultural self-identification of the Malorosians worked for regionalism, the allocation of local identity to the religion of service to the Russian Empire. Positive in this process were the search for cultural sources, determination of the peculiarities of the character of native Russian culture, their folklore, everyday life, and language, which in the future helped the new stage of the already Ukrainian revival and national liberation movement. It should be agreed that Russians as a whole were part of the historical process of developing the consciousness of the elite in the role of state institutions of Russia and foreign cultural domination. But it's not just about integrating Ukraine into the imperial space. Other factors that have encompassed a broad socio-cultural condition that integrate elements of integration and marginalization should be highlighted.

${ }^{17}$ Радзієвський В. Базові резонансні субкультури сучасної України: монографія. К.: Логос. 2014. С. 220-221.

${ }^{18}$ Когут 3. Російський централізм і українська автономія: Ліквідація Гетьманщини, 1760-1830. К.: Основи, 1996. С. 187. 
The crisis of traditional values also gives rise to various kinds of marginalized existence with its forms of social impatience, denial of existing social institutions. Margins are the social base of terrorism, incl. and revolutionary, especially when their social value system extends to other social groups and becomes the basis of political upheavals and revolutions.

This connection is well grounded in the monograph of V. Volkovinsky and I. Ikonikova, incl. peculiarities of the terrorist movement of Ukrainians ${ }^{19}$. Authors of such works are increasingly revealing the influence of ideology and activity of terrorist groups of different directions on sociocultural processes in Ukraine. At the same time, he is still waiting for his analysis of the issue of the features of political terrorism in the Ukrainian national liberation movement, its ethical justification and moral evaluations.

Unlike the Russians, the Ukrainians were formed in other socio-cultural coordinates. Kyiv Rus was part of the European civilization community. Grand Duchy of Lithuania, Commonwealth of Poland closely related to Western European cultural values. The new era politically united Ukrainians and Russians within a single state. The center of the union is faith, in other aspects it is difference, and so the empire began to erase it by assimilation. Among other consequences, this caused some amorphism in the sociopolitical and cultural activities of Ukrainians who lived in the Russian Empire, unlike the part under the rule of Austria-Hungary. It is only natural that some Ukrainians saw only the abuser in the state, and the Cossack Mamay became the ideal of life. This gave rise to a mass movement of anarchism led by Nestor Makhno.

In the political culture of Ukrainians, the view of violence as a duty is an attribute of power to which it is itself legitimized. Even in the regions of Ukraine where people have traditionally sought freedom, they have been hiding from harassment by the authorities. For a long time there was no real state power, which was usually not its own, in the South-East of Ukraine. Leadership functions were performed by local chieftains. Individual freedom was more important than in other regions of Ukraine and not in comparison with the values of the population of other regions of the Russian Empire. Conquering such people is the most effective force of terror possible. It should be noted another negative feature of the carriers of this mentality, which, in particular, emphasized E. Fromm: «This, at first glance, their independence seems to be like the inner strength and integrity pushing them to fight and any force that limits their freedom ... It is an attempt to assert themselves, to overcome the feeling of their own powerlessness, but a dream to obey, conscious or not, when this is preserved $\rangle^{20}$. This socio-cultural

19 Волковинський В., Іконікова І. Революційний тероризм в Російській імперії і Україна(ІІЦ пол. ХІХ - початок XX ст.). К.: Старий світ, 2006. 416 с.

${ }^{20}$ Фром Э. Бегство от свободы. Тайна порока. Харьков: Эдис, 1995. С. 168. 
peculiarity of a part of the Ukrainian society gives arguments to attribute Ukraine to the limit, which is, first of all, high level of conflict, feeling of peripherality, discomfort related to blocking of partisipation experience ${ }^{21}$. Addition to this position on limitroph as a zone of contact between local civilizations of steel and the assertion of the inevitability of this atmosphere of Manichean structures and the corresponding cultural worldview and outlook, which leads to the split of cultural consciousness. Therefore, «two programs of reproduction of the socio-cultural whole live and constantly update themselves in Ukrainian culture, which mutually disable one another. It is important to realize, - the authors emphasize, - that the split is happening through the consciousness of the native Ukrainian culture. Hence - the severity and lack of integration of the personal field, a number of instant inertial transitions and much more» ${ }^{22}$.

The author considers that such phenomena should be more constructively considered within the concept of postmodernity as a new cultural paradigm and interpreted as a special type of world view oriented towards the following values: freedom in everything, rejection of priorities, complete spontaneity in the activity of the individual, above all the artist. And, importantly, it should be used to analyze any period in the history of our socio-cultural development. Postmodernism is not just a modern methodology of sociocultural knowledge, but is a characteristic of social reality in which the attitude to chaos is a kind of order ${ }^{23}$.

It is clear that the epochal socio-cultural transformations that took place at the turn of New and Modern Times also caused crisis phenomena, which take on various forms of manifestation. The need for their analysis and rethinking is conditioned by the likelihood of their recurrence in our times when Ukrainian society has signs of a crisis society. It is promising to analyze the peculiarities of interaction in this situation of personality and nation. At the turn of XIX-XX centuries, processes of industrialization destroyed the structures of the traditional agrarian society, in which the dominant factor was the community and family, not individuals. The process of national formation itself was impossible without replenishment of the nation by individuals. The concept of the nation as an imaginary community of B. Anderson fully discloses this process. Leaders of national cultural movements developed sufficiently substantiated concepts of the nation and disseminated it through the system of education, literature and brought under

${ }^{21}$ Андрущенко В. Соціальна філософія: історія, теорія, методика. К.: Генеза, 2006. C. 624-627.

${ }^{22}$ Калакура Я., Рафальський О., Юрій М. Українська культура: цивілізаційний вимір. К.: ІПіЕНД ім. І. Ф. Кураса НАН України, 2015. С. 398-399.

23 Уварова Т. Постмодернізм як нова парадигма української культури. Аркадія. Культурологічний та мистечттвознавчий журнал. 2009. № 2(24). С. 13 
it a solid historical base. The most extensive scientific research was presented in the History of Russians, when the beginnings of the Ukrainians were associated with the Sarmatians, and later the concept of direct origin of Trypillians appeared. These and other scientific developments represented national formation as a long process, during which ethnic characteristics were formed, which became decisive at the final stage. In this context, constructivist and ethnocultural approaches have been combined whereby the freedom of self-determination of individuals and nations is an interconnected process and the rights of the individual must be upheld by the concept of national rights. From these points of view, nation-building can be seen as a response of the Ukrainian people to political-assimilation, further accelerating the collapse of political empires in the early twentieth century.

The socio-cultural specificity of Ukraine is also in the relationship of different ethnic groups, especially with regard to Russians and Poles. So armed speeches of Poles of 1830-1831 and 1863-1864 took place in RightBank Ukraine and influenced the relations of representatives of these ethnic groups. The repression of the tsarist authorities against the insurgents was quite widespread, but there was no doubt in their status as a national minority. At the same time, Russification of the region is increasing. Thus, the Ukrainians were not denied the formal equality of individuals, but were not recognized as a separate national community. On the territory of AustriaHungary, the Ukrainian population had certain rights, but they were largely offset by the position of Polish citizenship, which was the main opponent of granting political rights and freedoms to Ukrainians. At the beginning of the twentieth century, this conflict of political elites has grown into a confrontation between peoples, which is gaining ground ${ }^{24}$. This situation, on the other hand, contributed to the growth of national consciousness and the radicalization of national movements of both Ukrainians and Poles. We also feel its consequences in the current context of the relations between the two peoples, especially regarding the historical past.

At the heart of civilizational knowledge of political culture should be placed such a category as the «picture of the world», i.e. the system of ideas, a set of knowledge and views on the surrounding world and its structure. Typically, this category performs an orientation function in the knowledge of human activity. Specifying the problems, it should be noted that in these circumstances the tradition of independent existence of Ukrainians in the political field from Russia and Poland is realized. It is clear that not everyone in these countries agrees with such approaches, but for us this means self-denial of our own history and national identity.

Thus, within the framework of modernity, profound socio-cultural changes are taking place in Ukraine, which have markedly influenced the

${ }^{24}$ Субтельний О. Україна: історія. К.: Либідь, 1991. С. 290. 
character of people's thinking. The more traditional positivist worldview of the XIX century was replaced by modernism. He paid attention to the spiritual values and life practices of people who have been marginalized the notion of race, people, life, etc. Moreover, the usual notions were filled with other content within the philosophy of culture. The process of human life on the basis of systematic, orderly, ethics of modest work and philosophy of small affairs was changed by the destruction of the routine of human life. Its place was taken by the energy of impulse, the creative life of the individual not bound by duties and responsibilities. This approach actively penetrated into the sphere of political culture, where the notion of freedom of creativity of the individual, independence from everyday life, and superficial attitude towards everyday life occupy an increasingly prominent place. Life was thought of as a value filled with struggle, creativity, embodiment of utopian ideals. Of course, this was a protest against the then lifestyle based on calculation and practicalism, against the subjection of human rigid standards of behavior. But, an approach to the formation of a special type of individual that will assert a new way of life, including totalitarianism of the twentieth century, is unambiguously formed in its various versions, because modernism is also characterized by such a component of ideology as totality, the desire for mass.

Modernization processes became the basis for the creation of modern nations, and the catalyst for the rise of the national movement were the revolutionary events of the early twentieth century and the First World War. They accelerated the transformation of traditional lifestyles and, as a result, Ukrainian self-determination became a fact of history, and its independence became a concrete manifestation of the proclamation of Ukrainian statehood.

\section{CONCLUSIONS}

The study of the process of becoming a political culture, its place and role in the structure of the Ukrainian society becomes more synergistic and complex within the framework of the interaction of the humanities, which allows clarifying its influence on the assertion of identity of the Ukrainian nation more thoroughly. Drawing on the work of domestic and foreign researchers, using different scientific methods of cognition, the author tries to explore the leading tendencies of the formation of political culture in complex socio-political conditions, considering it as a process of long evolutionary character.

This process should be considered more in line with the socio-cultural development of our society. The changes of modern times were in line with modernism, which brought a new outlook and a new ideology at the heart of the idea of human ability to change the world. It is about a radical change of world outlook, creation of new paradigms of political thinking. This revolution, which continues in the current context, is closely linked to 
radical changes in all spheres of socio-cultural life. The author considers that when considering modernization processes it is necessary to understand the transition from the traditional society to the modern is always dramatic, there are different deviations from the general rules of modernization, and accordingly, there are complications. Therefore, from these positions the process of formation of political culture of the Ukrainian people is characterized against the background of significant changes in society. Systematic historical analysis shows that socio-cultural processes most adequately reflect the transitional changes characteristic of modern times, and in particular, the essence of transformations at the turn of the nineteenth and twentieth centuries.

The presence of their own cultural field, the carriers of which demonstrated the potential of integration of different styles and values, which laid the foundation for the renewal of the political mentality of Ukrainians in modern times, formed a new socio-cultural environment. This has had a significant impact on the consciousness of the social communities of all parts of Ukraine, above all on their traditional behavior and collective perceptions, i.e. key features of political culture. The processes of politicization of the Ukrainian society were unequal in the pace of development in the Russian and Austro-Hungarian empires, which demoralizingly affected the worldview and values of all groups of the population, especially the upper echelons of Ukrainian society. The growth of political consciousness and activity of the Ukrainians was hampered by elements of Russians and Russophiles, which contributed only to the defense in the regional consciousness of Russians and Poles. Cultural, social movements were not noticeable in nature until the end of the nineteenth century, which reflected on the nature of political culture.

Despite such factors and circumstances, the national idea in the early twentieth century is becoming widespread among the intelligentsia and other groups of society, and thanks to the various socio-political and cultural activities of the Ukrainians, first of all in Austria-Hungary and then on the lands controlled by the Russian Empire, they are transformed into a national community with their own political culture for the purpose of living in their own state.

- Ukraine is in a state of transition in its political history, and there is no clear picture of the current period of our past in the public consciousness. There is a difference of opinion both at the level of the collective and individual layers of consciousness of the majority of citizens of modern Ukraine. Therefore, an analysis of the essence of political culture, the peculiarities of its origins and the functioning of its various types can be productive, provided the historical approach, restoration of the completeness of historical and cultural memory of the Ukrainian people. This provides more opportunities for a comprehensive analysis of the essence of the 
political culture of Ukrainians and for understanding the dynamics of change in the role and place of Ukraine in European and world civilizations.

In today's context, the civilizational choice of Ukraine has a significant influence on the evolution of political culture, which is increasingly evolving as a synthesis of traditional domestic traits of political mentality with the adaptation of pan-European values, which opens a wider space for the formation of a modern political nation in Ukraine.

\section{SUMMARY}

The paper analyzes the process of becoming political culture of Ukrainian society in difficult conditions of influence of various external and internal factors. The author pays special attention to the consideration of scientific approaches that significantly expand the subject field of political culture functioning in the conditions of transformation of society. The problem of changes in the manifestation of political culture in different state organisms and especially the factor of preserving its identity in the absence of state support is investigated.

\section{REFERENCES}

1. Аджи М. Европа, Тюрки, Великая Степь. М.: ООО «Издательство АСТ», 2004. 473 с.

2. Андрущенко В., Губерський Л. В., Михальченко М. І. Соціальна філософія: історія, теорія, методика. К.: Генеза, 2006. 728 с.

3. Волковинський В., Іконікова I. Революційний тероризм в Російській імперії і Україна(II пол. XIX - початок XX ст.). К.: Старий світ, 2006. 416 с.

4. Грицак Я. Нариси історій України. Формування модерної української нації XIX-XX століть. К.: Генеза,1998. 360 с.

5. Губернський Л., Андрущенко В., Калакура Я., Михальченко М. Ідеологія, особистість, методолого-світоглядний аналіз. К.: Знання України, 2002. 580 с.

6. Гумилев Л. Н. Древняя Русь и Великая Степь. М.: Товарищество «Клышников - Комаров и К», 1992. 512 с.

7. Іванченко Р. П. Історія без міфів: бесіди 3 історії української державності : навч. посіб. 2-ге вид., переробл. і допов. К.: МАУП, 2006. $624 \mathrm{c}$.

8. Калакура Я., Рафальський О., Юрій М. Українська культура: цивілізаційний вимір. К.: ІПіЕНД ім. І. Ф. Кураса НАН України, 2015. $496 \mathrm{c.}$

9. Касьянов Г. В. Український націоналізм: проблема наукового переосмислення. Украӥнський історичний журнал. 1998. № 2. С. 39-54.

10. Когут 3. Російський централізм i українська автономія: Ліквідація Гетьманщини, 1760-1830. К.: Основи, 1996. 317 с. 
11. Кривицька О. Дискурс пограниччя в соціокультурних дослідженнях: теоретично-методологічні аспекти. Наукові записки: ІПЕНДім. І. Ф. Кураса НАН Украӥни. 2015. Вип. 4(78). С. 173-197.

12. Малес Л. Розуміючий потенціал соціокультурного аналізу.Якісні дослідження в соиіологічних практиках: Навч. посібник / За ред. Н. Костенко, Л. Скокової. К.: Інститут соціології НАНУ, 2009. C. 77-95.

13. Нагорна А. Історична культура: концепт, інформаційний ресурс, рефлексивний потенціал. К.: ІПіЕНД ім.І.Ф.Кураса НАН України, 2014. $382 \mathrm{c.}$

14. Проблеми теорії ментальності / Ред. М. В. Попович. К.: Наукова думка, 2006. 404 с.

15. Радзієвський В. Базові резонансні субкультури сучасної України: монографія. К.: Логос, 2014. 661 с.

16. Резник В. Теоретико-методологические семинары в Институте социологии НАН Украины. Социология: теория, методы, маркетинг. 2013. № 3. С.180-187.

17. Рюзен Й. Нові шляхи історичного осмислення. Львів: Літопис, 2010. 358 с.

18. Субтельний О. Україна: історія. К.: Либідь, 1991. 512 с.

19. Уварова Т. Постмодернізм як нова парадигма української культури. Аркадія. Культурологічний та мистеитвознавчий журнал. 2009. № 2(24). С. 12-16.

20. Фром Э. Бегство от свободы. Тайна порока. Харьков: Эдис, 1995. C. 168.

21. Шевченко Н.В. «Ягелонська спадщина» у світлі сучасних українських історичних студій. Історичний архів. Миколаїв, 2008. Т. 1. C. 29-39.

22. Шейко В. Культура України в глобально-цивілізаційному вимірі (історико-методологічні аспекти). К.: Інститут культурології НАМ України, 2011. 624 с.

23. Юрій М.Ф. Соціокультурний світ України: Моногр. 2-е вид. К.: Кондор, 2004. 736 с.

\section{Information about the author: Sushko A. I., Associate Professor,} Associate Professor at the Department of Political Theories of the National University «Odessa Law Academy» 2, Academichna str., Odesa, 65009, Ukriane 